Ariyanti, M. • S. Rosniawaty · M.R. Permana

\title{
Respons pertumbuhan tanaman kelapa belum menghasilkan terhadap pemberian air kelapa dan asam humat
}

\section{Response of immature kopyor coconut plant (Cocos nucifera L.) growth on coconut water and humic acid application}

Diterima : 26 Agustus 2019/Disetujui : 10 Desember 2019 / Dipublikasikan : 31 Desember 2019

CDepartment of Crop Science, Padjadjaran University

\begin{abstract}
Kopyor coconut demand usually increase because its endosperm has unique character, but kopyor coconut productivity is still low. The growth of young kopyor coconut can be improved by natural Plant Growth Regulation (PGR) such as coconut water and humic acid as an organic material for improving soil properties. The research was purposed to find out the effect of the combination of coconut water and humic acid applications on young kopyor coconuts plant growth. The research was conducted at Mekarsari Fruit Garden, Cileungsi, Bogor, West Java, from May 2018 to October 2018. The soil ordo was Ultisols. The experimental method used randomized block design (RDB) with 11 treatments and 3 replications. The treatments consisted of various combination of coconut water concentrations: 50\%, 75\%, 100\%; humic acid dose: $10 \mathrm{~mL} / \mathrm{L}, 20$ $\mathrm{mL} / \mathrm{L}, 30 \mathrm{~mL} / \mathrm{L}$ per plant; and $100 \%$ coconut water and $30 \mathrm{~mL} / \mathrm{L}$ humic acid as controls. The results showed that combination of the treatment $75 \%$ coconut water $+20 \mathrm{~mL}$ humic acid has the best response to addition of plant height on 16, 20, and 24 week after treatment (WAT) while the treatment $100 \%$ coconut water $+20 \mathrm{~mL}$ humic acid has the best response to addition of plant trunks on 8 until 24 WAT.
\end{abstract}

Keywords: Kopyor coconut - Coconut water • Humic acid

\footnotetext{
Dikomunikasikan oleh Memet Hakim dan Mochamad Arief Soleh

Ariyanti, M. ${ }^{1}$ · S. Rosniawaty ${ }^{1}$ · M.R. Permana ${ }^{2}$

${ }^{1}$ Departemen Budidaya Pertanian, Fakultas Pertanian,

Universitas Padjadjaran.

2 Sarjana Program Studi Agtoteknologi, Fakultas Pertanian

, Universitas Padjadjaran.

Jl. Raya Bandung-Sumedang km.21, Jatinangor, Jawa

Barat, Indonesia.

Korespondensi : mira.ariyanti@unpad.ac.id
}

Sari. Kelapa kopyor banyak diminati masyarakat karena memiliki sifat yang unik. namun produktivitas kelapa kopyor masih rendah. Peningkatan pertumbuhan kelapa kopyor belum menghasilkan dapat dilakukan dengan aplikasi zat pengatur tumbuh alami (ZPT) seperti air kelapa yang diaplikasikan langsung pada tanaman dan asam humat sebagai bahan organik untuk meningkatkan kualitas tanah agar dapat sesuai bagi pertanaman kelapa kopyor. Penelitian ini bertujuan untuk mengetahui pengaruh kombinasi aplikasi air kelapa dan asam humat terbaik terhadap pertumbuhan tanaman kelapa kopyor belum menghasilkan. Penelitian dilaksanakan di Lahan Taman Buah Mekarsari, Cileungsi, Bogor, Jawa Barat, pada bulan Mei 2018-Oktober 2018. Penelitian ini menggunakan tanah berordo Ultisols. Metode penelitian yang digunakan yaitu rancangan acak kelompok (RAK) dengan 11 perlakuan dan tiga ulangan. Perlakuan terdiri dari kombinasi aplikasi air kelapa dengan konsentrasi 50\%,75\%, $100 \%$ dengan dosis asam humat $10 \mathrm{~mL} / \mathrm{L}, 20$ $\mathrm{mL} / \mathrm{L}, 30 \mathrm{~mL} / \mathrm{L}$ per tanaman serta aplikasi air kelapa $100 \%$ dan asam humat $30 \mathrm{~mL} / \mathrm{L}$ per tanaman sebagai kontrol. Hasil penelitian menunjukan kombinasi aplikasi air kelapa 75\% + asam humat $20 \mathrm{~mL}$ memberikan respons terbaik terhadap pertambahan tinggi tanaman pada 16, 20, dan 24 minggu setelah perlakuan sedangkan kombinasi aplikasi air kelapa 100\% + asam humat $20 \mathrm{~mL}$ memberikan respons terbaik terhadap pertambahan lilit batang pada $8-24$ minggu setelah perlakuan.

Kata kunci: Kelapa kopyor - Air kelapa · Asam humat 


\section{Pendahuluan}

Kelapa merupakan pohon kehidupan (tree of life) karena seluruh bagian tanaman dapat dimanfaatkan. Salah satu varietas kelapa diantaranya varietas kopyor. Kelapa kopyor (Cocos nucifera L. var. Kopyor) merupakan tanaman kelapa yang secara genetik menghasilkan buah kelapa dengan ciri daging buahnya (endosperm) lepas dari batoknya dan bertekstur remah (Riyadi, 2015). Produktivitas kelapa kopyor masih dikategorikan rendah yaitu sekitar 2,1 \% dari keseluruhan produksi kelapa. Hal tersebut disebabkan karena petani masih menggunakan benih yang berasal dari tandan yang menghasilkan buah kelapa kopyor dengan tingkat pengelolaan tanaman yang rendah (Riyadi, 2015). Hal tersebut dilakukan dengan asumsi bahwa tanaman kelapa yang menghasilkan kelapa kopyor akan selalu menghasilkan kopyor padahal kenyataannya tidak seperti itu. Kelapa kopyor dihasilkan dari keabnormalan pertumbuhan buah kelapa dari tanaman yang mungkin saja tidak menghasilkan buah kopyor secara terus menerus. Selain itu, kesesuaian lahan yang optimal bagi pertumbuhan tanaman kelapa kopyor masih kurang diperhatikan. Berkaitan dengan ini diperlukan variasi teknologi budidaya tanaman kelapa guna menunjang peningkatan pertumbuhan vegetatif kelapa kopyor khususnya pada masa TBM (tanaman belum menghasilkan) yang diharapkan akan berpengaruh positif terhadap produksi kelapa kopyor pada masa TM (tanaman menghasilkan).

Variasi teknologi budidaya tanaman kelapa kopyor dapat dilakukan diantaranya dengan aplikasi air kelapa sebagai zat pengatur tumbuh (ZPT) alami dan asam humat sebagai bahan organik untuk perbaikan sifat tanah yang kurang sesuai untuk ditanami kelapa kopyor. Zat pengatur tumbuh ini akan menjadi pendorong percepatan pertumbuhan tanaman jika diaplikasikan dengan dosis yang tepat dan optimal. Faktor jenis tanaman, fase tumbuh tanaman, jenis ZPT, konsentrasi dan cara aplikasi ZPT ini akan memberikan pengaruh respons positif tanaman yang diakibatkan dari aplikasinya (Fahmi, 2014).

Sumber ZPT sitokinin dan auksin alami pada tanaman kelapa adalah air kelapa. Winarto (2015) menyatakan bahwa air kelapa mengandung komposisi kimia yang unik yang terdiri dari mineral, vitamin, gula, asam amino, dan fitohormon yang memiliki efek signifikan terhadap pertumbuhan tanaman. Penggunaan ZPT air kelapa dengan konsentrasi 75\% dan 100\% mampu meningkatkan pertumbuhan setek batang dan panjang tunas jati (Renvillia et al., 2016). Darlina et al. (2016), menyatakan bahwa penyiraman air kelapa $200 \mathrm{~mL} / \mathrm{L}$ berpengaruh nyata terhadap jumlah daun, bobot basah, dan bobot kering terbaik tanaman lada. Pemberian air kelapa dengan konsentrasi 100\% menghasilkan respons terbaik pada pertumbuhan luas daun kelapa pada fase TBM dan air kelapa dengan konsentrasi $50 \%$ cenderung menghasilkan peningkatan pertumbuhan tinggi tanaman kelapa TBM (Ariyanti et al., 2018). Perlakuan 50\% air kelapa dan campuran antara 50\% urin kelinci $+25 \%$ air kelapa menghasilkan tinggi tanaman, jumlah daun, diameter batang, jumlah anakan, dan berat kering rimpang jahe merah yang baik pada 20 minggu setelah tanam ( MST) (Kusnadi dan Tivani, 2017).

Kondisi lahan atau media tanam yang kurang sesuai untuk pertanaman kelapa kopyor dapat diperbaiki dengan aplikasi asam humat. Asam humat berasal dari hasil dekomposisi lignin atau karbohidrat pada tanaman yang kaya akan karbon dan juga mengandung nitrogen (Tan, 2003). Kuvaini (2014) menyatakan bahwa asam humat berperan dalam memperbaiki kesuburan tanah dengan adanya peningkatan kapasitas tukar kation (KTK) di dalam tanah, pengikatan ion $\mathrm{Al}$ dan $\mathrm{Fe}$ yang bersifat racun bagi tanaman, dan memacu pertumbuhan mikroorganisme tanah. Menurut Ariyanti et al. (2019), aplikasi $30 \mathrm{~mL}$ asam humat yang dikombinasikan dengan 3200 g pupuk organik asal pelepah kelapa sawit menghasilkan pertumbuhan tinggi tanaman dan kandungan klorofil daun yang terbaik setelah empat bulan perlakuan pada kelapa sawit TBM.

Penelitian ini bertujuan untuk mengetahui respons pertumbuhan kelapa kopyor TBM akibat pemberian air kelapa dan asam humat dan mengetahui dosis terbaik campuran air kelapa dan asam humat dalam meningkatkan pertumbuhan kelapa kopyor TBM.

\section{Bahan dan Metode}

Penelitian ini dilaksanakan pada bulan Mei 2018 sampai Oktober 2018 di Lahan Taman Buah Mekarsari, Cileungsi, Bogor, Jawa Barat. Letak Geografis Taman Buah Mekarsari adalah $6^{\circ}-35^{\circ}$ LS dan $52^{\circ}-106^{\circ} \mathrm{BT}$ dengan kemiringan lahan 0 - $8 \%$ serta ketinggian tempat \pm 70 meter di atas 
permukaan laut (mdpl). Berdasarkan klasifikasi Schmidt dan Ferguson (1951), tipe iklim di Taman Buah Mekarsari termasuk tipe iklim A.

Bahan dan alat yang digunakan pada penelitian diantaranya kelapa kopyor genjah hijau belum menghasilkan umur 11 bulan, air kelapa muda, asam humat cair Humatani ${ }^{\circledR}$, aquadest, pupuk kandang sapi, gelas ukur, dan label tanaman.

Penelitian menggunakan Rancangan Acak Kelompok (RAK). Perlakuan yang diberikan terdiri dari sebelas perlakuan. Setiap perlakuan diulang sebanyak tiga kali dengan jumlah tanaman untuk setiap plot perlakuan dua buah tanaman. Perlakuan yang digunakan yaitu: $\mathrm{A}=$ asam humat $30 \mathrm{~mL}, \mathrm{~B}=$ air kelapa $100 \%, \mathrm{C}=$ air kelapa $50 \%+$ asam humat $10 \mathrm{~mL}, \mathrm{D}=$ air kelapa $50 \%+$ asam humat $20 \mathrm{~mL}, \mathrm{E}=$ air kelapa 50\% + asam humat $30 \mathrm{~mL}, \mathrm{~F}=$ air kelapa $75 \%+$ asam humat $10 \mathrm{~mL}, \mathrm{G}=$ air kelapa $75 \%$ + asam humat $20 \mathrm{~mL}, \mathrm{H}$ =air kelapa $75 \%$ + asam humat $30 \mathrm{~mL}$, $\mathrm{I}=$ air kelapa $100 \%+$ asam humat $10 \mathrm{~mL}, \mathrm{~J}=$ air kelapa $100 \%$ + asam humat $20 \mathrm{~mL}, \mathrm{~K}=$ air kelapa $100 \%+$ asam humat $30 \mathrm{~mL}$.

Analisis ragam menggunakan uji $\mathrm{F}$ pada taraf kepercayaan 95\% dan uji lanjut berganda Duncan pada taraf kepercayaan 95\% dilakukan apabila terdapat perbedaan diantara perlakuan.

\section{Hasil dan Pembahasan}

Pertambahan tinggi tanaman. Air kelapa yang dicampur dengan asam humat berpengaruh terhadap pertambahan tinggi kelapa TBM pada
16 MSP, 20 MSP dan 24 Minggu Setelah Perlakuan (MSP) (Tabel 1). Perlakuan G (air kelapa 75\% + $20 \mathrm{~mL}$ asam humat) menunjukkan pertambahan tinggi tanaman lebih baik dibandingkan perlakuan lainnya, namun tidak berbeda nyata dengan perlakuan $\mathrm{K}$ (air kelapa $100 \%$ + asam humat $30 \mathrm{~mL}$ ) dan $\mathrm{F}$ (air kelapa $75 \%+$ asam humat $10 \mathrm{~mL}$ ). Pengaruh perlakuan yang diberikan pada kelapa kopyor TBM mulai terlihat empat bulan setelah perlakuan.

Pemberian baik asam humat maupun air kelapa yang dicampur beberapa lebih efektif pengaruhnya terhadap pertumbuhan tinggi tanaman kelapa kopyor dibandingkan pemberian keduanya secara tunggal (asam humat saja atau air kelapa saja). Hal ini terlihat bahwa dengan mencampur $75 \%$ air kelapa dan $20 \mathrm{~mL}$ asam humat berpengaruh lebih efektif terhadap pertumbuhan tinggi tanaman kelapa kopyor TBM. Kombinasi perlakuan air kelapa dan asam humat ini saling menunjang dalam pertumbuhan tanaman kelapa kopyor.

Semakin tinggi konsentrasi air kelapa maka semakin tinggi pula kandungan unsur hara di dalamnya dimana konsentrasi air kelapa. Hal ini diduga bahwa konsentrasi air kelapa dalam perlakuan G (air kelapa 75\% + asam humat 20 $\mathrm{mL}$ ) merupakan konsentrasi optimal dengan kandungan unsur hara dan hormon yang tinggi dalam menunjang pertumbuhan tinggi tanaman kelapa kopyor. Hal ini sejalan dengan hasil penelitian Renvillia et al., (2016) yang menyatakan bahwa konsentrasi air kelapa 75 \% $100 \%$ memberikan respons yang baik terhadap pertumbuhan tanaman jati (Tectona grandis).

Tabel 1. Pertambahan tinggi tanaman kelapa kopyor TBM akibat pemberian air kelapa dan asam humat pada 4 MSP - 24 MSP.

\begin{tabular}{lllllll}
\hline \multirow{2}{*}{ Perlakuan } & \multicolumn{7}{l}{ Rata-rata pertambahan tinggi tanaman $(\mathrm{cm})$} \\
\cline { 2 - 7 } & $4 \mathrm{MSP}$ & $8 \mathrm{MSP}$ & $12 \mathrm{MSP}$ & $16 \mathrm{MSP}$ & $20 \mathrm{MSP}$ & $24 \mathrm{MSP}$ \\
\hline $\mathrm{A}$ & 3,58 & 9,33 & 11,83 & $14,83 \mathrm{bc}$ & $16,92 \mathrm{~cd}$ & $19,25 \mathrm{bc}$ \\
$\mathrm{B}$ & 2,83 & 8,83 & 11,17 & $12,83 \mathrm{bc}$ & $14,00 \mathrm{~cd}$ & $16,04 \mathrm{c}$ \\
$\mathrm{C}$ & 5,75 & 10,17 & 12,75 & $14,17 \mathrm{bc}$ & $15,33 \mathrm{~cd}$ & $18,00 \mathrm{bc}$ \\
$\mathrm{D}$ & 3,58 & 7,08 & 9,25 & $11,33 \mathrm{c}$ & $12,33 \mathrm{~d}$ & $15,67 \mathrm{c}$ \\
$\mathrm{E}$ & 2,42 & 11,42 & 15,08 & $17,33 \mathrm{bc}$ & $18,75 \mathrm{bc}$ & $20,83 \mathrm{bc}$ \\
$\mathrm{F}$ & 3,92 & 11,00 & 14,75 & $17,33 \mathrm{bc}$ & $19,42 \mathrm{bc}$ & $23,08 \mathrm{ab}$ \\
$\mathrm{G}$ & 4,25 & 15,45 & 21,50 & $23,83 \mathrm{a}$ & $25,33 \mathrm{a}$ & $28,00 \mathrm{a}$ \\
$\mathrm{H}$ & 5,00 & 12,25 & 16,08 & $17,58 \mathrm{bc}$ & $18,58 \mathrm{bc}$ & $21,33 \mathrm{bc}$ \\
$\mathrm{I}$ & 4,92 & 10,17 & 13,83 & $15,33 \mathrm{bc}$ & $16,25 \mathrm{bc}$ & $18,42 \mathrm{bc}$ \\
$\mathrm{J}$ & 4,08 & 11,00 & 14,67 & $16,50 \mathrm{bc}$ & $17,92 \mathrm{bc}$ & $20,75 \mathrm{bc}$ \\
$\mathrm{K}$ & 5,83 & 14,50 & 16,75 & $19,00 \mathrm{ab}$ & $21,17 \mathrm{ab}$ & $23,75 \mathrm{ab}$ \\
\hline
\end{tabular}

Keterangan : angka yang diikuti notasi pada kolom yang sama menunjukkan perbedaan nyata menggunakan Uji Jarak Berganda Duncan pada taraf kepercayaan 95\%. 
Tabel 2. Rata-rata pertambahan lilit batang kelapa kopyor TBM akibat pemberian air kelapa dan asam humat pada 4, 8, 12, 16, 20 dan 24 MSP.

\begin{tabular}{cllllll}
\hline \multirow{2}{*}{ Perlakuan } & \multicolumn{7}{l}{ Rata-rata pertambahan lilit batang tanaman $(\mathrm{cm})$} \\
\cline { 2 - 7 } & $4 \mathrm{MSP}$ & $8 \mathrm{MSP}$ & $12 \mathrm{MSP}$ & $16 \mathrm{MSP}$ & $20 \mathrm{MSP}$ & $24 \mathrm{MSP}$ \\
\hline $\mathrm{A}$ & 1,08 & $1,92 \mathrm{~cd}$ & $2,50 \mathrm{~cd}$ & $3,00 \mathrm{~cd}$ & $3,67 \mathrm{c}$ & $4,17 \mathrm{~d}$ \\
$\mathrm{~B}$ & 1,08 & $1,50 \mathrm{~d}$ & $2,08 \mathrm{~d}$ & $2,83 \mathrm{~cd}$ & $3,42 \mathrm{c}$ & $4,08 \mathrm{~d}$ \\
$\mathrm{C}$ & 1,17 & $1,58 \mathrm{~cd}$ & $2,25 \mathrm{~d}$ & $2,71 \mathrm{~d}$ & $3,58 \mathrm{c}$ & $4,33 \mathrm{~d}$ \\
$\mathrm{D}$ & 1,25 & $1,83 \mathrm{~cd}$ & $2,67 \mathrm{~cd}$ & $3,00 \mathrm{~cd}$ & $3,92 \mathrm{bc}$ & $4,83 \mathrm{~cd}$ \\
$\mathrm{E}$ & 1,17 & $2,42 \mathrm{~b}$ & $3,33 \mathrm{bc}$ & $4,08 \mathrm{ab}$ & $4,54 \mathrm{bc}$ & $5,25 \mathrm{bc}$ \\
$\mathrm{F}$ & 1,25 & $2,33 \mathrm{bc}$ & $3,67 \mathrm{~b}$ & $4,08 \mathrm{ab}$ & $4,75 \mathrm{bc}$ & $5,83 \mathrm{ab}$ \\
$\mathrm{G}$ & 1,17 & $2,50 \mathrm{~b}$ & $3,33 \mathrm{bc}$ & $4,33 \mathrm{ab}$ & $4,83 \mathrm{bc}$ & $5,75 \mathrm{ab}$ \\
$\mathrm{H}$ & 2,00 & $3,42 \mathrm{a}$ & $3,92 \mathrm{ab}$ & $4,83 \mathrm{a}$ & $5,25 \mathrm{ab}$ & $6,08 \mathrm{ab}$ \\
$\mathrm{I}$ & 1,58 & $2,58 \mathrm{ab}$ & $2,83 \mathrm{~cd}$ & $3,17 \mathrm{~cd}$ & $4,00 \mathrm{bc}$ & $5,25 \mathrm{bc}$ \\
$\mathrm{J}$ & 1,50 & $3,38 \mathrm{a}$ & $4,33 \mathrm{a}$ & $4,83 \mathrm{a}$ & $5,58 \mathrm{a}$ & $6,50 \mathrm{a}$ \\
K & 1,58 & $2,25 \mathrm{bc}$ & $3,00 \mathrm{~cd}$ & $3,42 \mathrm{~cd}$ & $4,08 \mathrm{bc}$ & $4,67 \mathrm{~cd}$ \\
\hline
\end{tabular}

Keterangan : angka yang diikuti notasi pada kolom yang sama menunjukkan perbedaan nyata menggunakan Uji Jarak Berganda Duncan pada taraf kepercayaan 95\%.

Pemberian asam humat memberikan respons yang baik dalam pertambahan tinggi tanaman kelapa kopyor. Dosis asam humat 20 $30 \mathrm{~mL} / \mathrm{L}$ air pertanaman dalam perlakuan $\mathrm{G}$ (air kelapa $75 \%$ + asam humat $20 \mathrm{~mL}$ ) dan perlakuan K (air kelapa 100\% + asam humat $30 \mathrm{~mL}$ ) merupakan dosis optimal dalam meningkatkan pertumbuhan tinggi tanaman kelapa kopyor. Asam humat secara langsung memacu pertumbuhan tanaman melalui stimulasi aktivitas hormon auksin dan giberelin pada tanaman, dan juga memacu pertumbuhan secara tidak langsung melalui perbaikan sifat - sifat tanah dan penyediaan unsur hara makro dan mikro essensial (Tan, 2003).

Status kesuburan tanah pada tanah Ultisol yang rendah seperti C-organik dapat diatasi menggunakan aplikasi asam humat. Asam humat berperan meningkatkan status kesuburan tanah Ultisol sehingga optimal bagi pertumbuhan tanaman kelapa kopyor seperti peningkatan kandungan C-organik sebesar 510\% (Dirjenbun dalam Darwis, 1986).

Kandungan nitrogen yang optimal tersebut mampu menunjang pertumbuhan tinggi tanaman kelapa kopyor dengan baik. Menurut Mulyani dan Kartasapoetra (2002), unsur hara makro seperti N, P, K serta unsur hara mikro lainnya dalam jumlah yang cukup dapat menghasilkan pertumbuhan tanaman yang optimal.

Pertambahan lilit batang tanaman. Keadaan lilit batang suatu tanaman berkaitan langsung dengan kemampuan tanaman dalam menopang tubuhnya secara keseluruhan. Penyebab robohnya tanaman adalah keadaan batang yang tidak proporsional dengan tubuh tanaman dimana hal itu akan berakibat kematian tanaman. Campuran nutrisi yang menyumbang hara untuk pertumbuhan lilit batang menjadi kajian yang tidak kalah penting dibandingkan parameter pertumbuhan lainnya.

Pemberian air kelapa dan asam humat baik secara tunggal maupun campuran antara keduanya berpengaruh nyata mulai delapan minggu setelah perlakuan atau dua bulan setelah perlakuan. Dibandingkan pengaruhnya terhadap pertumbuhan tinggi tanaman, serapan hara yang berasal air kelapa dan asam humat lebih cepat terlihat pada pertumbuhan lilit batang. Tabel 2 menunjukkan bahwa pada umumnya perlakuan J (air kelapa 100\% + asam humat $20 \mathrm{~mL}$ ) berbeda nyata dengan perlakuan lainnya, namun tidak berbeda nyata dengan perlakuan $\mathrm{H}$ (air kelapa $75 \%$ + asam humat $30 \mathrm{~mL}$ ).

Air kelapa yang dicampur asam humat menghasilkan pengaruh yang lebih efektif terhadap pertumbuhan lilit batang dibandingkan dengan pemberian masingmasing secara tunggal. Asam humat kombinasi pada perlakuan J (air kelapa 100\% + asam humat $20 \mathrm{~mL}$ ) menunjukkan 55,88\% lebih efektif pengaruhnya terhadap pertumbuhan lilit batang tanaman jika dibandingkan dengan perlakuan kontrol A (asam humat tunggal). Air kelapa kombinasi pada perlakuan J (air kelapa 100\% + asam humat $20 \mathrm{ml}$ ) menunjukkan 59,31\% lebih efektif terhadap pertumbuhan lilit batang tanaman kelapa kopyor jika dibandingkan dengan perlakuan kontrol B (air kelapa tunggal).

Kombinasi perlakuan yaitu asam humat dan air kelapa ini dapat saling mempengaruhi 
peningkatan pertumbuhan lilit batang tanaman kelapa kopyor. Hal ini dimungkinkan oleh adanya stimulasi aktivitas sitokinin dengan aplikasi air kelapa yang dapat menginisiasi pembelahan dan pembesaran sel pada jaringan meristem batang (Winarno, 2015).

Hal tersebut juga sesuai dengan hasil penelitian Oksana (2012) yang menyatakan bahwa pertumbuhan sel pada tanaman dirangsang oleh sitokinin, selanjutnya sel-sel yang membelah tersebut akan membesar membentuk jaringan yang besar. Selain itu, air kelapa mengandung unsur fosfor $(\mathrm{P})$ sebesar 186 $\mathrm{mL} / \mathrm{L}$ air kelapa yang dapat mempengaruhi pertambahan lilit batang, karena unsur $\mathrm{P}$ berperan dalam pembelahan sel pada jaringan meristem batang (Rindengan dan Allorerung, 2004).

Perlakuan $\mathrm{H}$ dan $\mathrm{J}$ yang merupakan kombinasi air kelapa dan asam humat dengan konsentrasi air kelapa sebesar 75\% dan 100\% menunjukkan konsentrasi optimal dalam menunjang pertumbuhan lilit batang tanaman kelapa kopyor dibandingkan dengan perlakuan kontrol (A dan B). Asam humat juga memberikan pengaruh yang nyata terhadap pertumbuhan lilit batang tanaman dengan memperlancar respirasi dan penyerapan air yang penting dalam proses fotosintesis (Brady and Weil, 2002). Selain itu, asam humat dapat menyediakan unsur hara makro $\mathrm{C}$ dan $\mathrm{N}$ yang optimal bagi pertumbuhan tanaman kelapa kopyor. Kadar C dan N yang optimal berturut turut yaitu 4,5 - 10\% dan 0,2 - 0,5 \%, dapat menjadi pelengkap reaksi enzimatis dalam pertumbuhan lilit batang tanaman kelapa kopyor (Dirjenbun dalam Darwis, 1986).

Menurut Santi (2014), pemberian $15 \mathrm{~mL}$ asam humat terhadap bibit kakao dapat meningkatkan pertumbuhan vegetatif bibit tanaman. Berdasarkan hal tersebut, penggunaan 2 kali lipat dari dosis asam humat menjadi 30 $\mathrm{mL} /$ tanaman untuk tanaman belum menghasilkan dapat menjadi dosis optimal bagi pertumbuhan lilit batang tanaman kelapa kopyor, dengan ditunjukkan oleh perlakuan $\mathrm{H}$ (air kelapa 75\% + asam humat $30 \mathrm{~mL}$ ).

Pertambahan jumlah pelepah daun. Gambar 1 menunjukkan perlakuan D (air kelapa $50 \%$ + asam humat $20 \mathrm{~mL}$ ) dan perlakuan $\mathrm{H}$ (air kelapa $75 \%$ dan asam humat $30 \mathrm{~mL}$ ) memperlihatkan pertumbuhan jumlah pelepah daun yang cenderung baik dengan tren positif pada 4 MSP sampai 24 MSP. Hormon sitokinin berperan langsung dalam pembelahan sel dan pertumbuhan lateral dengan ditunjukkan tumbuhnya daun. Pemberian sitokinin pada tanaman dapat memacu tumbuhnya tunas yang kemudian akan membentuk daun.

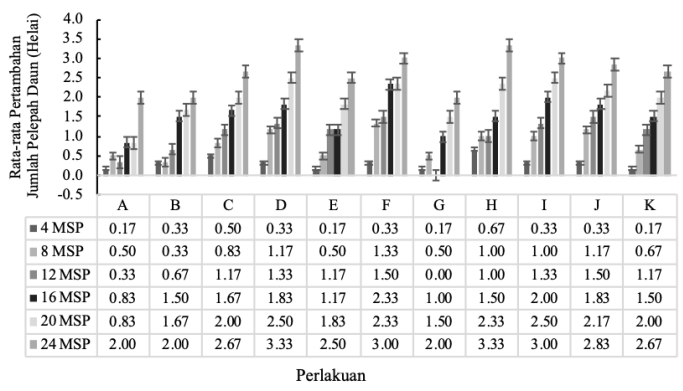

Gambar 1. Grafik rata - rata pertambahan jumlah pelepah daun kelapa kopyor TBM akibat pemberian air kelapa dan asam humat pada 4 MSP - 24 MSP.

Keterangan: Grafik perlakuan yang ditandai dengan huruf yang sama tidak berbeda nyata menurut Uji Lanjut Jarak Berganda Duncan pada taraf kepercayaan 95\%. Perlakuan A =asam humat $30 \mathrm{~mL}$ (kontrol); $\mathrm{B}=$ air kelapa 100\% (kontrol); C = air kelapa 50\% + asam humat $10 \mathrm{~mL}$; D =air kelapa 50\% + asam humat $20 \mathrm{~mL}$; E =air kelapa $50 \%$ + asam humat $30 \mathrm{~mL}$; F =air kelapa $75 \%+$ asam humat 10 $\mathrm{mL} ; \mathrm{G}=$ air kelapa 75\% + asam humat $20 \mathrm{~mL} ; \mathrm{H}=$ air kelapa $75 \%$ + asam humat $30 \mathrm{~mL}$; I =air kelapa $100 \%$ + asam humat $10 \mathrm{~mL}$; J =air kelapa $100 \%$ + asam humat $20 \mathrm{~mL} ; \mathrm{K}$ =air kelapa $100 \%$ + asam humat 30 $\mathrm{mL}$.

Perlakuan yang diberikan tidak berpengaruh secara nyata. Faktor penyebab adalah kondisi lingkungan yang kering pada bulan Juli hingga Agustus dengan rata - rata curah hujan bulanan sekitar $44-62,7 \mathrm{~mm}$ /bulan (rendah) sedangkan curah hujan yang optimal bagi tanaman kelapa kopyor adalah 108 - 190 mm/bulan (Puslitbangbun, 2014).

Tanaman akan merespons kekurangan air dan beradaptasi untuk mempertahankan diri pada kondisi kekeringan melalui berbagai mekanisme fisiologis dan biokimia. Hormon memegang peranan penting bagi tanaman menghadapi cekaman, salah satu hormon yang penting adalah asam absisat (ABA). Hormon ABA merupakan hormon pengendali stres dalam tanaman yang memiliki fungsi ganda, menginduksi gen-gen yang mengatur perlindungan terhadap cekaman air serta memacu penutupan stomata daun (Seki et al., 2002). 
Luas daun tanaman. Luas daun berkaitan dengan cakupan bidang daun yang dapat menyerap cahaya yang digunakan untuk proses fotosintesis. Semakin luas daun maka akan semakin banyak cahaya yang dapat ditangkap daun dan pastinya akan berpengaruh terhadap proses fotosintesis yang terjadi dalam menghasilkan fotosintat. Pemberian air kelapa dan asam humat belum berpengaruh secara nyata terhadap luas daun kelapa kopyor TBM sampai dengan enam bulan setelah pemberian (Gambar 2). Menurut Paramita et al. (2014), luas daun tidak dipengaruhi oleh pemberian hormon sitokinin alami berupa air kelapa melainkan lebih dipengaruhi oleh keadaan lingkungan. Curah hujan pada bulan Oktober yaitu 280 $\mathrm{mm} /$ bulan yang melebihi curah hujan optimal bagi tanaman kelapa kopyor yang berkisar 190 $\mathrm{mm} /$ bulan. Intensitas hujan yang tinggi menyebabkan intensitas cahaya matahari menjadi rendah, kondisi tersebut menyebabkan tanaman secara umum memperluas daunnya untuk mengoptimalkan penyerapan cahaya matahari (Sutarmi, 1983).

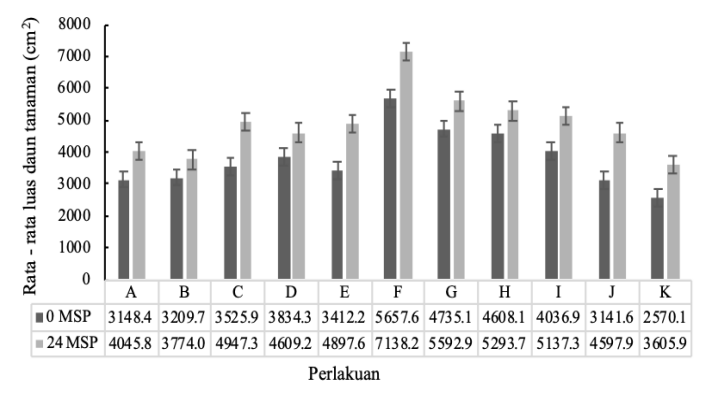

Gambar 2. Grafik rata-rata luas daun kelapa kopyor TBM akibat pemberian air kelapa dan asam humat pada 0 dan 24 MSP.

Keterangan: Grafik perlakuan yang ditandai dengan huruf yang sama tidak berbeda nyata menurut Uji Lanjut Jarak Berganda Duncan pada taraf kepercayaan 95\%.. Perlakuan A =asam humat $30 \mathrm{~mL}$ (kontrol); B = air kelapa 100\% (kontrol); C = air kelapa $50 \%+$ asam humat $10 \mathrm{~mL} ; \mathrm{D}$ =air kelapa $50 \%$ + asam humat $20 \mathrm{~mL}$; $\mathrm{E}=$ air kelapa $50 \%$ + asam humat 30 $\mathrm{mL} ; \mathrm{F}=$ air kelapa $75 \%$ + asam humat $10 \mathrm{~mL} ; \mathrm{G}=$ air kelapa $75 \%$ + asam humat $20 \mathrm{~mL} ; \mathrm{H}=$ air kelapa $75 \%$ + asam humat $30 \mathrm{~mL}$; I =air kelapa 100\% + asam humat $10 \mathrm{~mL}$; J =air kelapa $100 \%+$ asam humat 20 $\mathrm{mL}$; $\mathrm{K}=$ air kelapa $100 \%$ + asam humat $30 \mathrm{~mL}$.

Pengaruh terhadap peningkatan luas daun tampak pada perlakuan E (air kelapa 50\% + 30 $\mathrm{mL}$ asam humat) yang mampu meningkatkan luas daun sebesar $1485,4 \mathrm{~cm}^{2}$ sedangkan perlakuan B (air kelapa 100\%) hanya mampu meningkatkan luas daun sebesar 564,3 $\mathrm{cm}^{2}$ meskipun kedua perlakuan tersebut memberikan pengaruh yang tidak nyata berdasarkan uji Fisher pada taraf kepercayaan 95\%. Aplikasi asam humat diduga menunjang dalam penyediaan unsur hara makro dan mikro karena memiliki kapasitas tukar kation yang tinggi. Air kelapa yang dicampur dengan asam humat mampu menyediakan unsur hara yang lebih cukup dibandingkan dengan pemberian air kelapa saja sehingga dapat dikatakan bahwa asam humat berfungsi sebagai pendamping yang baik dalam penyediaan unsur hara bagi tanaman. Asam humat kaitannya dengan kemampuannya dalam meningkatkan KTK tanah tampaknya membantu penguraian unsur hara yang terkandung dalam pupuk organik sehingga relatif lebih tersedia bagi tanaman. Hal ini selaras dengan penelitian Ariyanti et al. (2019) dimana pupuk organik asal pelepah kelapa sawit (3200 g) yang diberikan bersamaan $30 \mathrm{~mL}$ asam humat menghasilkan pertumbuhan tinggi tanaman dan kandungan klorofil daun terbaik pada empat bulan setelah perlakuan kelapa sawit TBM.

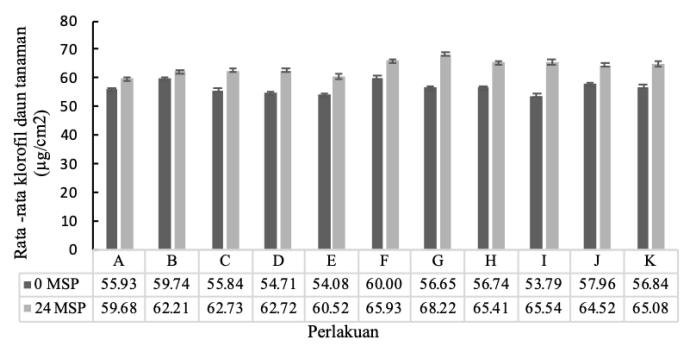

Gambar 3. Grafik rata - rata kandungan klorofil daun kelapa kopyor TBM akibat pemberian air kelapa dan asam humat pada 0 dan 24 MSP.

Keterangan: Grafik perlakuan yang ditandai dengan huruf yang sama tidak berbeda nyata menurut Uji Lanjut Jarak Berganda Duncan pada taraf kepercayaan 95\%.. Perlakuan A =asam humat $30 \mathrm{~mL}$ (kontrol);i B = air kelapa 100\% (kontrol); C = air kelapa $50 \%+$ asam humat $10 \mathrm{~mL} ; \mathrm{D}$ =air kelapa 50\% + asam humat $20 \mathrm{~mL} ; \mathrm{E}=$ air kelapa 50\% + asam humat $30 \mathrm{~mL} ; \mathrm{F}$ =air kelapa 75\% + asam humat $10 \mathrm{~mL} ; \mathrm{G}$ =air kelapa $75 \%$ + asam humat $20 \mathrm{~mL} ; \mathrm{H}$ =air kelapa 75\% + asam humat $30 \mathrm{~mL}$; I =air kelapa 100\% + asam humat $10 \mathrm{~mL}$; J =air kelapa $100 \%$ + asam humat $20 \mathrm{~mL} ; \mathrm{K}$ =air kelapa $100 \%$ + asam humat $30 \mathrm{~mL}$.

Kandungan klorofil daun tanaman. Daun sebagai organ vegetatif yang berperan dalam menyelenggarakan fotosintesis memegang peranan penting dalam menjamin kelangsungan 
hidup tanaman. Salah satu komponen penting untuk dapat terselenggaranya proses fotosintesis adalah adanya klorofil (zat hjau) daun. Daun dengan kandungan klorofil yang cukup dapat menopang kebutuhan tanaman khususnya untuk proses fotosintesis.

Pemberian air kelapa dan asam humat tidak berpengaruh nyata terhadap klorofil daun tanaman kelapa kopyor pada 0 MSP dan 24 MSP (Gambar 3). Hal tersebut diduga karena keadaan lingkungan pada bulan Oktober yang dapat menghambat dalam pembentukkan klorofil pada daun tanaman. Rata - rata curah hujan yang tinggi melebihi rata-rata optimal curah hujan bagi tanaman kelapa kopyor akan menyebabkan tingkat penyinaran menjadi rendah, hal tersebut akan menghambat pembentukkan klorofil daun. Hal ini sejalan dengan pernyataan Yohanis (2009) yaitu faktor faktor yang mempengaruhi pembentukkan klorofil antara lain gen, cahaya dan unsur N, $\mathrm{Mg}, \mathrm{Fe}$ sebagai pembentuk dan katalis dalam sintesis klorofil.

Gambar 3 menunjukkan adanya peningkatan kandungan klorofil daun kelapa kopyor dengan perlakuan air kelapa dan asam humat dalam kurun waktu 0 MSP - 24 MSP. Perlakuan G (air kelapa 75\% + asam humat $20 \mathrm{~mL}$ ) memperlihatkan peningkatan kandungan klorofil daun yang baik yaitu $11,57 \mu \mathrm{g} / \mathrm{cm}^{2}$ selama kurun waktu 6 bulan atau peningkatan $2 \mu \mathrm{g} / \mathrm{cm}^{2}$ setiap bulannya. Hal tersebut diduga akibat kombinasi perlakuan air kelapa dan asam humat dapat saling menunjang dalam peningkatan kandungan klorofil daun tanaman kelapa kopyor. Air kelapa yang diberikan langsung pada tanaman ini mengandung hormon, asam amino, asam-asam organik, asam nukleat, purin, gula, vitamin, dan mineral (Netty, 2002). Salah satu bentuk hormon sitokinin adalah kinetin. Kinetin berperan penting dalam meningkatkan kandungan klorofil dalam daun sehingga memacu aktivitas fotosintensis dan mening-katkan pertumbuhan serta produksi tanaman (Gore dan Sreenivasa, 2011).

Pemberian asam humat yang diberikan pada tanah dapat menunjang pertumbuhan melalui penyediaan unsur hara nitrogen $(\mathrm{N})$ dan magnesium (Mg) bagi tanaman. Klorofil dapat terbentuk dengan memanfaatkan unsur hara $\mathrm{N}$ yang tersedia bagi tanaman, dimana klorofil berperan sebagai penangkap cahaya yang dibutuhkan dalam proses fotosintesis dan unsur magnesium sebagai penyusun molekul klorofil (Wardiana dan Mahmud, 2003).

\section{Kesimpulan}

1. Aplikasi air kelapa dan asam humat memberikan respons yang baik terhadap pertumbuhan tanaman kelapa kopyor belum menghasilkan, terutama pada pertambahan tinggi dan lilit tanaman kelapa kopyor.

2. Perlakuan yang menunjukkan respons terbaik diantaranya perlakuan G (air kelapa $75 \%+20 \mathrm{~mL}$ asam humat) yang menghasilkan pertumbuhan tanaman tertinggi. Perlakuan perlakuan $\mathrm{H}$ (air kelapa $75 \%$ + asam humat $30 \mathrm{~mL}$ ) dan perlakuan J (air kelapa 100\% + asam humat $20 \mathrm{~mL}$ ) menghasilkan pertambahan lilit batang tertinggi pada kelapa kopyor TBM.

\section{Daftar Pustaka}

Ariyanti, M., Rosniawaty, S., Indrawan, R.A. 2019. Pertumbuhan kelapa sawit belum menghasilkan dengan pemberian pupuk organik asal pelepah kelapa sawit dan asam humat. J. Pen. Kelapa Sawit 27(2): 7182.

Ariyanti, M., Suherman, C., Maxiselly, Y., Rosniawaty, S. 2018. Pertumbuhan tanaman kelapa (Cocos nucifera L.) dengan pemberian air kelapa. Jurnal Hutan Pulaupulau Kecil 2(2): 201-212.

Brady, N.C., Weil, R.R. 2002. The Nature and Properties of Soils. 13th ed. Prentice Hall. New Jersey.

Darlina, Hasanuddin, Rahmatan, H. 2016. Pengaruh Penyiraman Air Kelapa terhadap Pertumbuhan Vegetatif Lada (Piper nigrum. L). Jurnal Biologi. Unsyiah. Aceh.

Darwis, S.N. 1986. Tanaman Kelapa dan Lingkungan Pertumbuhannya. Balai Penelitian Kelapa Manado.

Fahmi, Z.I. 2014. Kajian pengaruh auksin terhadap perkecambahan benih dan pertumbuhan tanaman. Direktorat Jenderal Pertanian. http://ditjenbun.pertanian. go.id. Diakses 28 Desember 2017.

Gore, N.S., Sreenivasa, M.N. 2011. Influence of liquid organic manures on growth, nutrient content and yield of tomato (Lycopersicon esculentum Mill.) in the sterilized soil. Karnataka Journal of Agricultural Sciences. 24 (2): 153-156. 
Kusnadi dan Tivani, I. 2017. Pengaruh pemberian urine kelinci dan air kelapa terhadap pertumbuhan rimpang dan kandungan minyak atsiri jahe merah. Jurnal Kultivasi 16 (3) : 444-450.

Kuvaini, A. 2014. Respon pertumbuhan bibit kelapa sawit (Elaeis guineensis Jacq.) terhadap pemberian pupuk NPK dan asam humat padat di pembibitan awal. Jurnal Citra Widya Edukasi 6 (1): 10-19.

Mulyani, S. M. dan A.G. Kartasapoetra. 2002. Pupuk dan Cara Pemupukan. Rineka Cipta, Jakarta.

Netty, W. 2002. Optimasi medium untuk multiplikasi tunas kana (Canna hibryda Hort.) dengan penambahan sitokinin. J. Biosains dan Bioteknologi Indonesia 2 (1) : 27-31.

Oksana., Rahmadani, E., Syamsul. 2012. Peranan berbagai macam media tumbuh bagi pertumbuhan stek daun jeruk J.C (Japanche citroen) dengan beberapa konsentrasi BAP. Jurnal Agroteknologi 2(2).

Paramita, G., Indradewa, D., Waluyo, S. 2014. Pertumbuhan bibit tujuh klon teh (Camellia sinensis (L.) Kuntze) PGL dengan pemberian bahan mengandung hormon tumbuh alam. J. Vegetalika 42(6): 1-12.

Puslitbangbun (Pusat Penelitian dan Pengembangan Perkebunan). 2014. Pedoman Budidaya Kelapa yang Baik. Buku Pedoman. Direktorat Jenderal Perkebunan. Jakarta.

Renvillia, R., Bintoro, A., Riniarti,M. 2016. Penggunaan air kelapa untuk stek batang Jati (Tectona grandis). J. Sylva Lestari 4(1): 61-68.

Rindengan, B., dan Allorerung, D. 2004. Potensi dan pengolahan buah kelapa muda. Monograf pasca panen. Balitka Manado. Hal. 55-56.

Riyadi, I. 2015. Penanaman dan Perawatan Tanaman Kelapa Kopyor asal Kultur
Jaringan. Buku Panduan PPBBI. Pusat Penelitian Bioteknologi dan Bioindustri Indonesia.

Santi, L. P. 2014. Pengaruh asam humat terhadap pertumbuhan bibit kakao (Theobroma cacao ) dan populasi mikroorganisme di dalam tanah humik. Jurnal Tanah dan Iklim 40(2) : 87-94.

Schmidt, F. H., Ferguson, J.H.A. 1951. Rainfall Type Based on Wet and Dry Period. Ratio for Western Indonesia with New Guinea. Kementrian Perhubungan, Jawatan Meteorologi dan Geofisika. Jakarta.

Seki, M., Ishida, J., Narusaka,M., Fujita, M., Nanjo,T., Umezawa, T., Kamiya, A., Nakajima, M., Enju, A., Sakurai, T., Satou, M., Akiyama, K., Yamaguchi-Shinozaki, K., Carninci, P., Kawai, J., Hayashizaki, Y., Shinozaki, K. 2002. Monitoring the expression pattern of around 7,000 Arabidopsis genes under ABA treatments using a full length cDNA microarray, Funct. Integr. Genomics 2 : 282-291.

Sutarmi, S. 1983. Botani Umum Jilid II. Angkasa. Bandung. 180 hal.

Tan, K.H. 2003. Humic Matter in Soil and Environment, Principles and Controversies. Marcel Dekker.Inc. Madison. New York.

Wardiana, E., dan Mahmud, Z. 2003. Tanaman sela diantara pertanaman kelapa sawit. Lokakarya Sistem Integrasi Kelapa SawitSapi: 175-187.

Winarto, B. 2015. Use of coconut water and fertilizer for in vitro proliferation and plantlet production of Dendrobium 'Gradita 3'. in vitro cell development. Biology Journal 51: 303 - 314.

Yohanis, N. 2009. Biokimia: Struktur dan Fungsi Biomolekul. Yogyakarta: Graha ilmu. 